\title{
Gaetbulibacter marinus sp. nov., isolated from coastal seawater, and emended description of the genus Gaetbulibacter
}

Correspondence

Jang-Cheon Cho

chojc@inha.ac.kr

\author{
Seung-Jo Yang and Jang-Cheon Cho
}

\author{
Division of Biology and Ocean Sciences, Inha University, Yonghyun-Dong, Incheon 402-751, \\ Republic of Korea
}

The genus Gaetbulibacter (Jung et al., 2005) is a member of the family Flavobacteriaceae (Bernardet et al., 2002; Bernardet \& Nakagawa, 2006; Reichenbach, 1989) and, at the time of writing, comprises one recognized species, Gaetbulibacter saemankumensis, isolated from a tidal flat sediment. G. saemankumensis is characterized by Gramnegative, yellow-pigmented, non-flagellated, rod-shaped cells that show gliding motility. In the present study, we describe a seawater strain, designated IMCC $1914^{\mathrm{T}}$, that represents a novel species of the genus Gaetbulibacter.

Strain IMCC $1914^{\mathrm{T}}$ was isolated from a surface seawater sample collected off the coast of Deokjeok island, Yellow Sea $\left(37^{\circ} 04^{\prime} \mathrm{N} 127^{\circ} 05^{\prime} \mathrm{E}\right)$, Korea, by using a standard dilution-plating method. The sample was diluted in filtered $(0.2-\mu \mathrm{m}$ mesh) and autoclaved seawater and spread on R2A agar (Difco) diluted in aged seawater (1:10, v/v, 1/ 10R2A). The agar plates were incubated aerobically at $20{ }^{\circ} \mathrm{C}$ for 1 month. Strain IMCC $1914^{\mathrm{T}}$ was grown on $1 /$ 10R2A and further purified on marine agar 2216 (MA; Difco) and stored as a suspension in $10 \%$ glycerol marine broth 2216 (MB; Difco) at $-80{ }^{\circ} \mathrm{C}$. After the optimum growth temperature had been determined, cultures were maintained on MA or in $\mathrm{MB}$ at $25{ }^{\circ} \mathrm{C}$. Unless otherwise indicated, phenotypic and biochemical characterizations were performed on $\mathrm{MA}$ at $25{ }^{\circ} \mathrm{C}$.

\footnotetext{
The GenBank/EMBL/DDBJ accession number for the $16 \mathrm{~S}$ rRNA gene
} sequence of strain IMCC $1914^{\top}$ is EF108219.
Growth temperature range and optimum were measured at $3-42{ }^{\circ} \mathrm{C}$ (at $3{ }^{\circ} \mathrm{C}, 10-30{ }^{\circ} \mathrm{C}$ at $5{ }^{\circ} \mathrm{C}$ intervals, 37 and $42{ }^{\circ} \mathrm{C}$ ) in $\mathrm{MB}$. The $\mathrm{pH}$ range and optimum for growth were examined at $\mathrm{pH} 4.0-12.0$ (at $0.5 \mathrm{pH}$ unit intervals). The $\mathrm{pH}$ was adjusted with $0.1 \mathrm{M} \mathrm{HCl}$ or $0.1 \mathrm{M} \mathrm{NaOH}$. The $\mathrm{NaCl}$ concentration range and optimum for growth were determined in $\mathrm{NaCl}$-free artificial seawater medium (ASW; per litre distilled water: $5.9 \mathrm{~g} \mathrm{MgCl}_{2} .6 \mathrm{H}_{2} \mathrm{O}, 3.24 \mathrm{~g}$ $\mathrm{MgSO}_{4} \cdot 7 \mathrm{H}_{2} \mathrm{O}, 1.8 \mathrm{~g} \mathrm{CaCl} 2.2 \mathrm{H}_{2} \mathrm{O}, 0.55 \mathrm{~g} \mathrm{KCl}, 0.16 \mathrm{~g}$ $\mathrm{NaHCO}_{3}, \quad 0.08 \mathrm{~g}$ KBr, $0.034 \mathrm{~g} \quad \mathrm{SrCl}_{2} .6 \mathrm{H}_{2} \mathrm{O}, 0.022 \mathrm{~g}$ $\mathrm{H}_{3} \mathrm{BO}_{3}, 0.008 \mathrm{~g} \mathrm{Na} \mathrm{H}_{2} \mathrm{PO}_{4}, 0.004 \mathrm{~g} \mathrm{Na}_{2} \mathrm{SiO}_{3}, 0.0024 \mathrm{~g}$ $\mathrm{NaF}$ and $0.0016 \mathrm{~g} \mathrm{NH}_{4} \mathrm{NO}_{3}$ ), supplemented with $5.0 \mathrm{~g}$ peptone, $1.0 \mathrm{~g}$ yeast extract and various concentrations of $\mathrm{NaCl}(0-5.0 \%$ at $0.5 \%$ intervals and $5.0-15.0 \%$ at $2.5 \%$ intervals; w/v). Cell morphology and size were examined by transmission electron microscopy (CM200; Philips) and phase-contrast microscopy (Nikon $80 \mathrm{i}$ ) by using a 4-day MB culture. Colony morphology, size and colour were examined from cultures grown aerobically on MA for 4 days. The MGC anaerobic system and an AnaeroPACK Anaero (Mitsubishi Gas Chemical company, Inc.) were used for anaerobic growth tests. Flagellar motility was examined by using wet mounts made from fresh cultures grown both on MA and in $\mathrm{MB}$ at $25{ }^{\circ} \mathrm{C}$ for 3 days. Gliding motility was determined by phase-contrast microscopy of cells incubated for $17 \mathrm{~h}$ on microscope slides coated with MA (0.7\% agar), initially grown in $\mathrm{MB}$ at $25{ }^{\circ} \mathrm{C}$ for 2 days, according to the method described by Bowman (2000). Gliding motility was also examined by using wet mounts, made from cultures grown in $\mathrm{MB}$ at $25{ }^{\circ} \mathrm{C}$ for 3 days. The 
presence of flexirubin-type pigments was determined by the bathochromatic shift test by using $20 \%(\mathrm{w} / \mathrm{v}) \mathrm{KOH}$ solution (Bernardet et al., 2002; McCammon \& Bowman, 2000). Cellular pigments were extracted with acetone/ methanol $(1: 1, \mathrm{v} / \mathrm{v})$ and their absorption spectra were determined by using a scanning UV/visible spectrophotometer (Optizen 2120UV; Mechasis Co.). The catalase test was performed by addition of $3 \%$ hydrogen peroxide to exponential-phase colonies, and oxidase activity was determined by using oxidase reagent (bioMérieux). Other biochemical tests were carried out on API 20NE and API ZYM strips (bioMérieux) according to the manufacturer's instructions and inoculated with bacterial suspensions in ASW. Carbon source oxidation tests were performed on GN2 microplates (Biolog) by using bacterial suspensions in filtered $(0.2-\mu \mathrm{m}$ mesh) and autoclaved seawater. Degradation of macromolecules was tested by incubating bacterial cultures on MA containing macromolecules at $25{ }^{\circ} \mathrm{C}$ for 14 days. The following macromolecules were tested (all w/v): starch $(0.2 \%)$, casein $(1 \%$ skimmed milk), elastin $(0.5 \%)$, chitin $(0.5 \%)$ and CM-cellulose $(0.2 \%)$. Hydrolysis was revealed by formation of clear zones around the colonies either directly or after flooding with adequate staining solutions (Teather \& Wood, 1982). Susceptibility to antimicrobial agents (see the species description below for list and concentrations) was determined by using the disc diffusion method (Jorgensen et al., 1999). The DNA $\mathrm{G}+\mathrm{C}$ content of strain IMCC1914 ${ }^{\mathrm{T}}$ was analysed by using HPLC according to Mesbah et al. (1989) with a Discovery C18 column $(5 \mu \mathrm{m}, 15 \mathrm{~cm} \times 4.6 \mathrm{~mm}$; Supelco). Cellular fatty acid methyl esters were extracted and prepared from cultures grown on MA at $25{ }^{\circ} \mathrm{C}$ for 4 days, and analysed according to the MIDI Microbial Identification System by the Korean Culture Center of Micro-organisms (KCCM).

The nearly full-length sequence of the 16S rRNA gene (1466 bp) of strain IMCC1914 ${ }^{\mathrm{T}}$ was obtained as described by Cho \& Giovannoni (2003). Comparative analysis of the 16S rRNA gene sequence of this strain with sequences held in GenBank showed that it belonged to the family Flavobacteriaceae. The 16S rRNA gene sequence of strain $\mathrm{IMCC}_{1914}{ }^{\mathrm{T}}$ was aligned with those of its nearest neighbours in the family Flavobacteriaceae by using the ARB software package (Ludwig et al., 2004) and 16S rRNA gene sequence similarity values were calculated based on this alignment in the ARB software. Comparative sequence analyses in the ARB database showed that strain IMCC1914 ${ }^{\mathrm{T}}$ was related most closely to G. saemankumensis SMK-12 (96.2\% similarity), followed by Flaviramulus basaltis $\mathrm{H} 35^{\mathrm{T}}$ $(96.0 \%)$ and Algibacter lectus KMM $3902^{\mathrm{T}}$ (95.7\%). To clarify the phylogenetic position of strain IMCC1914 ${ }^{\mathrm{T}}$ further, 1151 unambiguously aligned nucleotide positions were employed for phylogenetic analyses in PAUP ${ }^{*} 4.0$ beta 10 (Swofford, 2002). Phylogenetic trees were inferred by three tree-generating algorithms, neighbour joining (Saitou \& Nei, 1987) with the Jukes-Cantor model (Jukes \& Cantor, 1969), maximum parsimony (Fitch, 1971) and maximum likelihood (Felsenstein, 1981). Robustness of the resultant neighbour-joining and maximum-parsimony trees was evaluated by bootstrap analysis based on 1000 resamplings. In all of the phylogenetic trees generated in the present study (Fig. 1), strain IMCC1914 ${ }^{\mathrm{T}}$ formed a clade together with G. saemankumensis, although levels of bootstrap support for the clade were relatively low (62\% in the neighbour-joining tree and $51 \%$ in the maximumparsimony tree). This Gaetbulibacter clade formed a larger clade with $F$. basaltis in the neighbour-joining and maximum-likelihood trees, but bootstrap values for the clade did not support the relationship. DNA-DNA hybridization studies as used for demarcating bacterial species (Wayne et al., 1987) were not performed because the level of 16S rRNA gene sequence similarity between strain IMCC1914 ${ }^{\mathrm{T}}$ and G. saemankumensis was lower than $97 \%$ (Stackebrandt \& Goebel, 1994). The phylogenetic results coupled with 16S rRNA gene sequence similarity $(<97 \%)$ between strain IMCC1914 ${ }^{\mathrm{T}}$ and G. saemankumensis suggested that the strain should be assigned to the genus Gaetbulibacter as representing a novel species.

The phenotypic characteristics of strain IMCC $1914^{\mathrm{T}}$ are summarized in Table 1 and in the species description. In

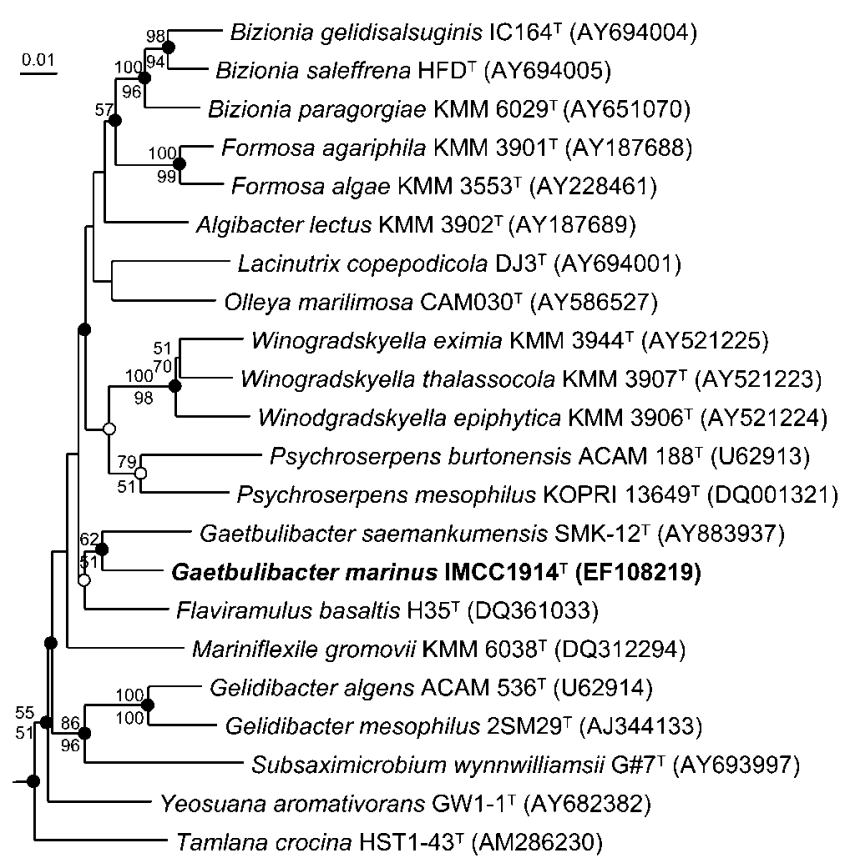

Fig. 1. Neighbour-joining phylogenetic tree, based on $16 \mathrm{~S}$ rRNA gene sequences, showing relationships between strain IMCC $1914^{\top}$ and representatives of the family Flavobacteriaceae. Bootstrap percentages ( $>50 \%$ ) from both neighbour joining (above nodes) and maximum parsimony (below nodes) are shown. Filled and open circles indicate nodes recovered by all three treeing methods or by two treeing methods, respectively. Bacteroides fragilis Bfr901 (GenBank accession no. X83945) was used as an outgroup (not shown). Bar, 0.01 substitutions per nucleotide position. 
Table 1. Differential phenotypic characteristics between strain IMCC $1914^{\top}$ and $\mathrm{G}$. saemankumensis

Data for G. saemankumensis strains are from Jung et al. (2005). +, Positive; -, negative; $\mathrm{w}$, weakly positive; $\mathrm{v}$, variable. All strains were positive for hydrolysis of aesculin and for catalase, alkaline phosphatase, esterase (C4), esterase lipase (C8), leucine arylamidase, valine arylamidase, cystine arylamidase and acid phosphatase activities, but negative for production of flexirubin-type pigments, gelatin liquefaction and $\alpha$-galactosidase, $\beta$-galactosidase, $\beta$-glucuronidase, $\alpha$-mannosidase and $\alpha$-fucosidase activities.

\begin{tabular}{|c|c|c|}
\hline Characteristic & IMCC1914 & $\begin{array}{l}\text { G. saemankumensis } \\
\qquad(n=3)\end{array}$ \\
\hline Gliding motility & - & + \\
\hline Facultatively anaerobic growth & - & + \\
\hline $\begin{array}{l}\text { Temperature range for growth } \\
\left({ }^{\circ} \mathrm{C}\right)\end{array}$ & $3-37$ & $13-40$ \\
\hline Growth with $7 \% \mathrm{NaCl}$ & - & + \\
\hline Oxidase activity & - & + \\
\hline Nitrate reduction & - & + \\
\hline \multicolumn{3}{|l|}{ Enzyme activities (API ZYM) } \\
\hline Lipase (C14) & - & + \\
\hline$\alpha$-Glucosidase & - & + \\
\hline$N$-Acetyl- $\beta$-glucosaminidase & - & + \\
\hline Trypsin & + & - \\
\hline $\begin{array}{l}\text { Naphthol-AS-BI- } \\
\text { phosphohydrolase }\end{array}$ & + & - \\
\hline$\alpha$-Chymotrypsin & + & $\mathrm{V}^{*}$ \\
\hline$\beta$-Glucosidase & $\mathrm{W}$ & $\mathrm{V}^{*}$ \\
\hline \multicolumn{3}{|l|}{ Hydrolysis of: } \\
\hline Casein & + & - \\
\hline Starch & - & + \\
\hline DNA G $+C$ content $(\mathrm{mol} \%)$ & 38.1 & $34.7-34.9$ \\
\hline
\end{tabular}

*The type strain is negative, whereas the other two strains described by Jung et al. (2005) are positive.

summary, cells of strain IMCC1914 ${ }^{\mathrm{T}}$ were Gram-negative, chemoheterotrophic, non-motile, obligately aerobic and lacked flexirubin-type pigments. The DNA G + C content (Table 1) and predominant cellular fatty acids (Table 2) of the strain were generally in good agreement with those of G. saemankumensis. However, several phenotypic properties, including gliding motility, oxidase activity, anaerobic growth and hydrolysis of macromolecules, differentiated strain IMCC $1914^{\mathrm{T}}$ from G. saemankumensis. $16 \mathrm{~S}$ rRNA gene sequence similarity and phylogenetic analyses, together with phenotypic characteristics, indicate that strain IMCC $1914^{\mathrm{T}}$ can be assigned to a novel species of the genus Gaetbulibacter, for which the name Gaetbulibacter marinus sp. nov. is proposed. Based on differential phenotypic characteristics of strain IMCC1914 ${ }^{\mathrm{T}}$ not reported in the description of the genus Gaetbulibacter by Jung et al. (2005), an emended description of the genus is presented.
Table 2. Cellular fatty acid composition of strain IMCC $1914^{\top}$ and $G$. saemankumensis

Data for G. saemankumensis strains are from Jung et al. (2005) and are given as values for the type strain, with values for the two other strains in parentheses. - , Not detected. Data are percentages of the total fatty acids; components that represent $>1.0 \%$ of the total cellular fatty acids of at least one of the strains are shown. All strains were grown on MA. Strain IMCC $1914^{\mathrm{T}}$ was grown at $25{ }^{\circ} \mathrm{C}$ for 4 days, whereas strains of G. saemankumensis were grown at $30{ }^{\circ} \mathrm{C}$ for 3 days.

\begin{tabular}{|lcc|}
\hline Fatty acid & IMCC1914 $^{\text {T }}$ & G. saemankumensis $(\boldsymbol{n}=3)$ \\
\hline $\mathrm{C}_{15: 0}$ & 3.9 & $1.5(1.3,1.6)$ \\
$\mathrm{C}_{16: 0}$ & 1.2 & $1.3(0.9,1.3)$ \\
iso- $_{13: 0}$ & 0.6 & $2.0(1.9,2.4)$ \\
iso- $_{14: 0}$ & 1.0 & - \\
iso- $_{15: 0}$ & 20.6 & $23.0(22.7,24.3)$ \\
iso- $\mathrm{C}_{15: 1}$ & 32.1 & $12.5(13.0,13.7)$ \\
iso- $\mathrm{C}_{16: 0}$ & 1.2 & - \\
anteiso- $\mathrm{C}_{15: 0}$ & 4.0 & $10.8(8.9,9.8)$ \\
anteiso- $\mathrm{C}_{15: 1}$ & 3.4 & $1.5(1.4,1.6)$ \\
iso- $_{17: 1} \omega 9 c$ & 0.3 & $2.1(2.2,2.4)$ \\
anteiso- $_{17: 1} \omega 9 c$ & - & $1.3(1.0,1.2)$ \\
$\mathrm{C}_{17: 1} \omega 6 c$ & 0.1 & $1.0(0.9,1.1)$ \\
iso- $\mathrm{C}_{15: 0} 3-\mathrm{OH}$ & 4.8 & $8.2(7.6,8.6)$ \\
iso- $\mathrm{C}_{16: 0} 3-\mathrm{OH}$ & 5.5 & $2.0(2.4,2.5)$ \\
iso- $\mathrm{C}_{17: 0} 3-\mathrm{OH}$ & 7.8 & $15.2(12.9,16.0)$ \\
$\mathrm{C}_{15: 0} 2-\mathrm{OH}$ & 0.6 & $1.6(1.4,1.6)$ \\
$\mathrm{C}_{17: 0} 2-\mathrm{OH}$ & 1.0 & $2.4(2.1,2.4)$ \\
$\mathrm{C}_{16: 0} 3-\mathrm{OH}$ & 1.2 & - \\
Summed feature $3 *$ & 4.5 & $10.4(8.2,10.4)$ \\
& & \\
\hline
\end{tabular}

${ }^{*}$ Summed feature 3 comprises $\mathrm{C}_{16: 1} \omega 7 c$ and/or iso- $\mathrm{C}_{15: 0} 2-\mathrm{OH}$.

\section{Emended description of Gaetbulibacter Jung et al. 2005}

The description of the genus Gaetbulibacter is as given by Jung et al. (2005) with the following amendments. Cells are obligately aerobic or facultatively anaerobic. Oxidase activity and gliding motility are species-dependent. The DNA G $+\mathrm{C}$ content is $34.7-38.1 \mathrm{~mol} \%$.

\section{Description of Gaetbulibacter marinus sp. nov.}

Gaetbulibacter marinus (ma.ri'nus. L. masc. adj. marinus of the sea, marine).

Cells are Gram-negative, chemoheterotrophic and obligately aerobic and show no flagellar or gliding motility. Cells in exponential phase are rods, $0.8-1.9 \mu \mathrm{m}$ long and $0.6-0.7 \mu \mathrm{m}$ wide. Flexirubin-type pigments are absent ( $\mathrm{KOH}$ test-negative). The yellow pigments (absorption peaks at 478 and $451 \mathrm{~nm}$ ) are probably of carotenoid type. After 5 days incubation, colonies on MA are circular, convex, entire, smooth, yellow-coloured and 1.0-3.0 mm in diameter. Growth occurs at $3-37{ }^{\circ} \mathrm{C}$ (optimum, $25^{\circ} \mathrm{C}$ ), at $\mathrm{pH} 8-11$ (optimum, $\mathrm{pH} 9$ ) and with $0.5-4.0 \% \mathrm{NaCl}$ 
(optimum, 1.0-1.5\%). Catalase-positive. Negative for nitrate reduction, indole production, acid production from glucose, hydrolysis of urea, oxidase, arginine dihydrolase and $\beta$ galactosidase activities and gelatin liquefaction (API 20NE strips). Casein is hydrolysed, but starch, elastin, CM-cellulose and chitin are not. Other enzyme activities determined by using API ZYM strips are given in Table 1. The following carbon substrates are oxidized (Biolog GN2 microplates): $\alpha$ cyclodextrin, dextrin, D-cellobiose, D-fructose, gentiobiose, $\alpha$-D-glucose, $\alpha$-D-lactose, maltose, D-mannose, methyl $\beta$-Dglucoside, sucrose, trehalose, turanose, succinic acid monomethyl ester, acetic acid, propionic acid, L-alaninamide, L-alanine, L-alanyl glycine, L-asparagine, L-aspartic acid, Lglutamic acid, glycyl L-aspartic acid, glycyl L-glutamic acid, hydroxy-L-proline, L-ornithine, L-proline, L-serine, L-threonine, $\alpha$-D-glucose 1-phosphate and D-glucose 6-phosphate. The following carbon substrates are not oxidized: glycogen, Tweens 40 and 80, N-acetyl-D-galactosamine, $N$-acetyl-Dglucosamine, adonitol, L-arabinose, D-arabitol, i-erythritol, L-fucose, D-galactose, myo-inositol, lactulose, D-mannitol, melibiose, D-psicose, raffinose, L-rhamnose, D-sorbitol, xylitol, pyruvic acid methyl ester, cis-aconitic acid, citric acid, formic acid, D-galactonic acid, D-galacturonic acid, Dgluconic acid, D-glucosaminic acid, D-glucuronic acid, $\alpha$-hydroxybutyric acid, $\beta$-hydroxybutyric acid, $\gamma$-hydroxybutyric acid, $p$-hydroxyphenylacetic acid, itaconic acid, $\alpha$-ketobutyric acid, $\alpha$-ketoglutaric acid, $\alpha$-ketovaleric acid, DL-lactic acid, malonic acid, quinic acid, D-saccharic acid, sebacic acid, succinic acid, bromosuccinic acid, succinamic acid, glucuronamide, D-alanine, L-histidine, Lleucine, L-phenylalanine, L-pyroglutamic acid, D-serine, DLcarnitine, $\gamma$-aminobutyric acid, urocanic acid, inosine, uridine, thymidine, phenylethylamine, putrescine, 2-aminoethanol, 2,3-butanediol, glycerol and DL- $\alpha$-glycerol phosphate. Susceptible to chloramphenicol $(25 \mu \mathrm{g})$, erythromycin $(15 \mu \mathrm{g})$, penicillin $\mathrm{G}(10 \mu \mathrm{g})$, tetracycline $(30 \mu \mathrm{g})$ and rifampicin $(50 \mu \mathrm{g})$, but resistant to vancomycin $(30 \mu \mathrm{g})$, ampicillin $(10 \mu \mathrm{g})$, gentamicin $(10 \mu \mathrm{g})$, kanamycin $(30 \mu \mathrm{g})$ and streptomycin $(10 \mu \mathrm{g})$. The major fatty acids are iso$\mathrm{C}_{15: 0}$, iso- $\mathrm{C}_{15: 1}$ and iso- $\mathrm{C}_{17: 0} 3-\mathrm{OH}$ (Table 2). The DNA $\mathrm{G}+\mathrm{C}$ content is $38.1 \mathrm{~mol} \%$.

The type strain, IMCC $1914^{\mathrm{T}}\left(=\mathrm{KCCM} 42380^{\mathrm{T}}=\mathrm{NBRC}\right.$ $102040^{\mathrm{T}}$ ), was isolated from seawater off Deokjeok-do, Yellow Sea, Republic of Korea.

\section{Acknowledgements}

This study was supported by the 21C Frontier programme of Microbial Genomics and Applications (grant MG05-0102-1-0) from the Ministry of Science and Technology, Republic of Korea.

\section{References}

Bernardet, J.-F. \& Nakagawa, Y. (2006). An introduction to the family Flavobacteriaceae. In The Prokaryotes, a Handbook on the Biology of Bacteria, 3rd edn, vol. 7, pp. 455-480. Edited by M. Dworkin, S. Falkow, E. Rosenberg, K. H. Schleifer \& E. Stackebrandt. New York: Springer.
Bernardet, J. F., Nakagawa, Y. \& Holmes, B. (2002). Proposed minimal standards for describing new taxa of the family Flavobacteriaceae and emended description of the family. Int J Syst Evol Microbiol 52, 1049-1070.

Bowman, J. P. (2000). Description of Cellulophaga algicola sp. nov., isolated from the surfaces of Antarctic algae, and reclassification of Cytophaga uliginosa (ZoBell and Upham 1944) Reichenbach 1989 as Cellulophaga uliginosa comb. nov. Int J Syst Evol Microbiol 50, 1861-1868.

Cho, J.-C. \& Giovannoni, S. J. (2003). Croceibacter atlanticus gen. nov., sp. nov., a novel marine bacterium in the family Flavobacteriaceae. Syst Appl Microbiol 26, 76-83.

Felsenstein, J. (1981). Evolutionary trees from DNA sequences: a maximum likelihood approach. J Mol Evol 17, 368-376.

Fitch, W. M. (1971). Toward defining the course of evolution: minimum change for a specific tree topology. Syst Zool 20, 406-416.

Jorgensen, J. H., Turnidge, J. D. \& Washington, J. A. (1999). Antibacterial susceptibility tests: dilution and disk diffusion methods. In Manual of Clinical Microbiology, pp. 1526-1543. Edited by P. R. Murray, E. J. Baron, M. A. Pfaller, F. C. Tenover \& R. H. Yolken. Washington, DC: American Society for Microbiology.

Jukes, T. H. \& Cantor, C. R. (1969). Evolution of protein molecules. In Mammalian Protein Metabolism, vol. 3, pp. 21-132. Edited by H. N. Munro. New York: Academic Press.

Jung, S. Y., Kang, S. J., Lee, M. H., Lee, S. Y., Oh, T. K. \& Yoon, J. H. (2005). Gaetbulibacter saemankumensis gen. nov., sp. nov., a novel member of the family Flavobacteriaceae isolated from a tidal flat sediment in Korea. Int J Syst Evol Microbiol 55, 1845-1849.

Ludwig, W., Strunk, O., Westram, R., Richter, L., Meier, H., Yadhukumar, Buchner, A., Lai, T., Steppi, S. \& other authors (2004). ARB: a software environment for sequence data. Nucleic Acids Res 32, 1363-1371.

McCammon, S. A. \& Bowman, J. P. (2000). Taxonomy of Antarctic Flavobacterium species: description of Flavobacterium gillisiae sp. nov., Flavobacterium tegetincola sp. nov., and Flavobacterium xanthum sp. nov., nom. rev. and reclassification of [Flavobacterium] salegens as Salegentibacter salegens gen. nov., comb. nov. Int J Syst Evol Microbiol 50, 1055-1063.

Mesbah, M., Premachandran, U. \& Whitman, W. B. (1989). Precise measurement of the $\mathrm{G}+\mathrm{C}$ content of deoxyribonucleic acid by highperformance liquid chromatography. Int J Syst Bacteriol 39, 159-167.

Reichenbach, H. (1989). Order I. Cytophagales Leadbetter 1974, $99^{\mathrm{AL}}$. In Bergey's Manual of Systematic Bacteriology, vol. 3, pp. 2011-2013. Edited by J. T. Staley, M. P. Bryant, N. Pfennig \& J. G. Holt. Baltimore: Williams \& Wilkins.

Saitou, N. \& Nei, M. (1987). The neighbor-joining method: a new method for reconstructing phylogenetic trees. Mol Biol Evol 4, 406-425.

Stackebrandt, E. \& Goebel, B. M. (1994). Taxonomic note: a place for DNA-DNA reassociation and $16 \mathrm{~S}$ rRNA sequence analysis in the present species definition in bacteriology. Int J Syst Bacteriol 44, 846-849.

Swofford, D. L. (2002). PAUP ${ }^{*}$ : Phylogenetic analysis using parsimony ( ${ }^{*}$ and other methods), version 4. Sunderland, MA: Sinauer Associates.

Teather, R. M. \& Wood, P. J. (1982). Use of Congo red-polysaccharide interactions in enumeration and characterization of cellulolytic bacteria from the bovine rumen. Appl Environ Microbiol 43, 777-780.

Wayne, L. G., Brenner, D. J., Colwell, R. R., Grimont, P. A. D., Kandler, O., Krichevsky, M. I., Moore, L. H., Moore, W. E. C., Murray, R. G. E. \& other authors (1987). International Committee on Systematic Bacteriology. Report of the ad hoc committee on reconciliation of approaches to bacterial systematics. Int J Syst Bacteriol 37, 463-464. 